\title{
The Comparative Impact of Reading Comprehension and Translation Practices on EFL Learners' Grammar Achievement
}

\author{
Maryam Kherad Ranjbar \\ Department of English Language Teaching, Shahr-e- Qods Branch \\ Islamic Azad University, Tehran, Iran \\ E-mail: maryam_ra23@yahoo.com
}

Dr. Kourosh Akef (Corresponding author)

Department of English Language, Central Tehran Branch

Islamic Azad University, Tehran, Iran

E-mail: kourosh.akef@gmail.com

Received: March 5, 2015 Accepted: August 26, 2015 Published: November 1, 2015

doi:10.5296/jse.v5i4.8321 URL: http://dx.doi.org/10.5296/jse.v5i4.8321

\begin{abstract}
This study focused on the comparative impact of teaching reading comprehension and translation practice on EFL learners' grammar achievement since previous studies have not directly dealt with the respective subject. In this study the total number of learners was 60 students attending in Poyandegan Rahe Kish institute. The current study utilized quantitative research methods to explore the implications of reading comprehension and translation by comparing their success rates in terms of grammar. Sixty participants out of 120 after going through a proficiency test for homogenization and a pilot test on the grammar questionnaire were divided into two experimental groups receiving instruction on reading comprehension in one group and translation in another each in 12 sessions (two sessions dedicated for pre and post test). At the end of the treatment, sample TOEFL grammar questionnaires were administered to both groups. To test the hypothesis, a T-test was employed concluding that the participants who received translation instruction and reading comprehension on grammar achievement. The analysis of data using an independent sample t-test indicated significant
\end{abstract}




\section{Macrothink}

Journal of Studies in Education

ISSN 2162-6952

2015, Vol. 5, No. 4

difference between the performances of experimental groups. The respective conclusion was that translation had a significant effect on EFL learners' grammar achievement.

Keywords: Reading Comprehension, Learners' Grammar Achievement, Translation Practice 


\section{Introduction}

According to Longman Dictionary of contemporary English grammar is: "The rules by which words change their forms and are combined into sentences, or the study or use of these rules" (Longman Dictionary of contemporary English, 2001, p. 619). There seem to be a variety of different concepts of what grammar is, including various terms, such as functional grammar, universal grammar or theoretical grammar (Odlin, 1994, p.74). Within the context of foreign language learning and teaching there is descriptive grammar which "describes, in a systematic way, the rules that govern how words are combined and sequenced in order to form sentences" and pedagogical grammar, which explores grammar more from a teaching/learning point of view (Thornbury, 2006, p.92).

Reading Comprehension is defined as the level of understanding of a text/message. This understanding comes from the interaction between the words that are written and how they trigger knowledge outside the text/message (Mark Seidenberg, 2001, p.31). A long line of studies, dating back to 1950, appears to prove little to no positive result from teaching grammar with regards to improvement in students' reading and/or writing skills (Weaver, 1997, p.45). Nowadays, many ESL practitioners view grammar less as a body of knowledge to be studied than as a skill to be practiced and developed. Knowledge of grammar is important, but only insofar as it enables students to communicate "accurately, meaningfully, and appropriately" (Larsen-Freeman, 2001, p.35). The English teacher is often portrayed as an "unattractive grammars monger whose only pleasure in life is to point out the faults of others" (Baron, 1982, p. 226).

For the purpose of this paper grammar will be referred to mostly from a pedagogical point of view dealing with a particular grammar point from a teacher's / foreign language student's perspective; learners understand grammatical rules from the examples so that the presentation of grammatical rules can be comprehended through the writings that are to be read.

According to Mandler \& Johnson, in both L1 and ESL, students who have been taught how to identify text structure and use this knowledge to guide their reading process have showed better comprehension and recall of information than readers lacking such knowledge (Mandler \& Johnson, 1977). Students who are reading texts need to work actively at finding and using appropriate cues in texts in order to enhance their understanding. Hence, even though reading comprehension is mostly conceptual, it still is affected by the knowledge of grammar either directly or indirectly (Gass \& Schacter, 1989).

When the issue turns to second language (L2) reading, the role of grammar becomes more complex. For one, L2 reading differs from L1 reading in that L2 readers "start to read in the second language before achieving the kind of grammatical maturity and the level of oral vocabulary that L1 readers attain before they begin to read" (Shiotsu, 2009, p. 16). Thus, L2 learners must learn how phrases are constructed and cases are assigned to the constructed phrases in a new language (Koda, 2007,p.122).

Cohen (1986) defined reading strategies as the mental process chosen by the reader consciously in order to achieve certain reading tasks. In addition to Cohen, Block (1986) 
believes that reading strategies are a set of methods and techniques used by readers, so that they can achieve success in reading. However, McNamara (2007) sees that reading strategies refer to the different cognitive and behavioural actions readers use under the purpose of achieving comprehension in reading. Also, Gough (1985) claims that the bottom up processing involves a series of steps the reader has to go through i.e. a series that involve moving from a step to another one, departing from recognizing the key features of every letter and then words, sentences until reaching the meaning of the text. On the other hand, other researchers focus on the top-down approach that is conceptually driven. This approach encourages students to use their background knowledge in order to make predictions about the texts they read (Smith, 1985).

A significant outcome of the use of reading strategies resides mainly in the capability to achieve meaningful reading. Reading strategies, such as prediction, skimming, scanning, inferring, guessing the meaning of unfamiliar words and self monitoring are effective reading strategies, which enable EFL learners to achieve comprehension when reading successful one of the most serious problems in higher education, but one which is often not recognized by either students or lecturers until some way into academic courses, is the problem of reading, perhaps because reading per se is not assessed. However, the results or outputs from reading are assessed.( Levine et al. 2000, p. 1) state: "the ability to read academic texts is considered one of the mostly Important skills that university students of English as a Second Language (ESL) and English as a Foreign Language (EFL) need to acquire".

As Rivers (1981) asserted, among the four second language skills, reading is the most stable and durable one. There has been a great deal of research about the different aspects of reading comprehension (Ediger, 1993, cited in Celce- Murcia, 2001, Kasmer, 1999); however, little has ever been done on the effect of translation on more efficient reading comprehension. Translation has been used by many language learners to facilitate language learning for centuries but, under different language teaching methods, it has played different roles.

The term translation itself has different meanings: It can be referred to as the general subject field, the product (the text has been translated) or the process (the act of producing translation, known as translating). The translation between two separate languages includes the translator rendering an original written text(the source text o $\mathrm{r}$ ST)in the original verbal language(the source language or SL) into a written text(the target text or TT)in a different verbal language(the target language or TL) (Munday, 2001).

It is also a widely held view that translation is not a suitable exercise in the initial stages of learning (Marsh, 1987). It is argued that, before learners can tackle translation productively, they need to have acquired a significant level of proficiency in the L2 language. They need to have moved beyond beginner's level.

Newson (1988) argued that using translation as a teaching and testing tool has four disadvantages. Translation (1) encourages thinking in one language and transferring to another, with accompanying interference; (2) deprives teacher and learner of the benefit of working within a single language; (3) gives false belief of the idea that there is a perfect one-to-one correspondence between languages; and (4) does not facilitate achievement of generally 
accepted aims such as emphasis on the spoken language. Liao (2006) summarizes the positive aspects of using translation: (1) it can help students comprehend L2; (2) it can help students to check whether their comprehension is correct; (3) it eases memory constraints in memorizing more words, idioms, grammar, and sentence structures; (4) it can help students develop and express ideas in another language; and (5) it can help reduce learning anxiety and enhance motivation to learn L2.

Accordingly the teacher/researcher tried to apply translation and reading techniques to assess the acquired results on ESL learners' grammar since Bassnett (1998) believed that "translation offers a crucial lesson in how to read, since it is a critical way into the text." She saw it as an effective means of forcing students to read texts thoughtfully and to concentrate on the lexical, grammatical and textual levels, and improving general knowledge, while "unveiling students' problems in comprehending (English) texts" (Brini, 2000).

\section{Review of Literature}

\subsection{Reading Comprehension}

Reading Comprehension is "the ability to understand and interpret language, whether spoken, written, or signed" (Crystal, 1992, p.77). Reading comprehension refers to "perceiving a written text in order to understand its contents" (Richards el al, 1992, p.306). Comprehension means building up meaning from words; it is the central both to academic and lifelong learning. According to (Snow, 2002, p. 7) reading comprehension is: The process of simultaneously extracting and constructing meaning through interaction, and involvement with written language. It consists of three elements: the reader, the text and the activity or purpose for reading.

Comprehension means building up meaning from words; it is the central both to academic and lifelong learning. According to (Snow, 2002, p. 7) reading comprehension is:

The process of simultaneously extracting and constructing meaning through interaction, and involvement with written language. It consists of three elements: the reader, the text and the activity or purpose for reading.

Comprehension is a process in which readers filter understanding through the lens of their motivation, knowledge, cognitive abilities and experiences. Effective readers have a purpose for reading, and use their background knowledge and experiences to relate to the text: readers don't comprehend unless they draw connections between what they read and their background knowledge Tankersley (2003). Furthermore, Pang et al (2003) described reading comprehension as an active process a reader made to construct meaning from a text. This process which consists of using an interaction between a prior knowledge, and drawing inferences from the different words and expressions the writer uses, in order to comprehend information, ideas and viewpoints. Smith (1985) also believes that reading comprehension involves bringing a prior knowledge interacted with what $\mathrm{s} / \mathrm{he}$ is reading, so that $\mathrm{s} / \mathrm{he}$ can achieve comprehension.

Reading comprehension is operationally defined as a task to improvement what he/she is 
reading as evidenced by correct responses on questions about the text and grammatical points in the related book.

\subsection{Learners’ Grammar Achievement}

Grammar is the structural foundation of ability to express one self. The more one aware of how it works, the more one can monitor the meaning and effectiveness of the way one and others use language. It can help foster precision, detect ambiguity, and exploit the richness of expression available in English. And it can help everyone-not only teachers of English, but teachers of anything, for all teaching are ultimately a matter of getting to grips with meaning. (David Crystal, "In Word and Deed," TES Teacher, April 30, 2004).

"Just as a pedagogical grammar can be regarded as a description of the grammar of a language made for teaching and learning purposes, to aid in the teaching and learning of that language, so pedagogical phonetics and phonology can be regarded as a description of the sound system and pronunciation of a language for the purpose of allowing teachers to teach it more effectively and learners to learn it more effectively. The point about pedagogical grammars is that they are not the same as linguistic grammars because they have different functions and uses." David Taylor, "What Do EFL Teachers Need to Know About (Pronunciation)?"( In Studies in General and English Phonetics, edited by Joseph Desmond O'Connor and Jack Windsor Lewis, Routledge, 1995). "Drawing on work in several fields such as linguistics, psychology and second language acquisition theory, pedagogical grammar is of a hybrid nature, which usually denotes grammatical analysis and instruction designed for the needs of second language students.

In its expanded view it involves decision making processes on behalf of the teacher which requires careful and time-consuming interdisciplinary work. This process is influenced by the teachers' cognition, beliefs, assumptions, and attitudes about the teaching of grammar." (Nagyné Foki Lívia, "From Theoretical to Pedagogical Grammar: Reinterpreting the Role of Grammar in English Language Teaching," dissertation, University of Pannonia, 2006).

In this prospective study, Learners' Grammar Achievement is operationally defined as the learners' improvement over obtaining a higher score based on their performance in the related TOEFL Test.

\subsection{Translation Practice}

Researcher Ross (2000) states that translation is recognized as the fifth skill and the most important social skill since it promotes communication and understanding. As a form of communication, translation involves interaction and cooperation between people, which makes it a very useful tool in foreign language teaching.

Translating from L2 into L1 seems to be natural, but what about a more demanding task, rendering L1 into L2? It is certainly advisable to stick to the former mode at lower levels and leave the latter for a more advanced stage, although some very simple L1-L2 translation activities, especially those involving awareness raising, can also be carried out at the initial stages of learning. (Deignan, 1997, Szabo, 1996, Lazar, 1996). 
Translation is a serious business which requires careful preparation both on the part of the teacher and the learner. Distributing a text and telling students "translate" is not a very good way to start. Carefully graded preparatory activities are necessary, and they can be integrated in reading, listening and writing activities, and also in vocabulary and grammar practice. Since translation is time consuming, it is advisable that longer pieces should be done at home. Occasionally, separate classes can be devoted to translation, but only with a highly motivated class. The teacher should ensure that these tasks are done as pair or group work. The purpose of this is to give the learners a chance to discuss, test and compare their ideas. (Harmer, 1991, p. 162, Ellis, 1992, p. 49, Nunan, Lamb, 1996, p. 99).

The purpose of translation in the language classroom is not to train professionals, but to help learners develop their knowledge of English. In other words, it is a means to an end, not an end to be achieved. However, some learners may become translators one day, and the basic knowledge of translation that they have gained in the classroom can serve as a solid ground for building up translation skills. (Friedlander, 1990, p.110).

Translation in foreign language classes is in the process of becoming a form of "pedagogical translation", which is no longer viewed as an ineffective tool in language learning and is evaluated as a way to enrich learners' competences.

Students taught by using pedagogical translation are encouraged to practice reading, writing, vocabulary, grammar, speaking. One of the main aims of foreign language teaching is to develop the student's ability to communicate in the target language. Researcher Ross (2000) states that translation is recognized as the fifth skill and the most important social skill since it promotes communication and understanding.

As a form of communication, translation involves interaction and cooperation between people, which makes it a very useful tool in foreign language teaching.

Translation heightens language awareness. While translating students are focused on identifying differences in structure and vocabulary, they have to evolve strategies to deal with them and to negotiate the potential of both languages. The real usefulness of translation in foreign language classes lies in comparison of grammar, vocabulary, word order and other language points in the target language and the student's mother tongue. Students are directly exposed to contrasting language systems of the target and the native languages. Therefore, the learners should be required to discuss and correct common mistakes. It may be appropriate at this point to mention Perkins's (1985) observations:

In order to develop in the students a linguistic awareness of contrast between L1 and L2 grammatical structures, and thus counteract interlingual interference, the teacher can quite legitimately get students to translate L1 sentences designed to pinpoint and clarify structures and patterns the student still has not assimilated. The material for translation should be interesting and varied, expressive and related to the learners' knowledge.

As students should cover different aspects of the foreign language, the material is required to be authentic, diverse in terms of structure and function. The teacher's task is to assess students' needs and select material to illustrate particular aspects of the language and the 
structure which present difficulties for students in the English language. By working through these difficulties students are able to see the link between the language and its use.

According to Duff (1994), translation happens everywhere and all the time. The students translate in class for other students, interpret signs and notices in the environment, and translate instructions, letters for friends and relatives. Moreover, they mentally translate ideas from their mother tongue into English.

Translation might provide a guided practice in reading. Before starting translating a text it "should be read carefully and analyzed in detail to determine the contents in terms of what, how and why it is said" (Leonardi, 2009, p.143).

Translation practice is operationally defined not to train professional translators, but translation here means more than just substitution of words in one language with those from another. Therefore reading passages were given to the learners to translate the text based on the instructed lesson in each session.

\section{Research Question}

In accordance with the objectives of the study, the following research question was formulated:

Q.Is there a significant difference between the impact of reading comprehension and translation practice on EFL learners' grammar achievement?

\section{Methodology}

\subsection{Participants}

The participants of this study included 60 Iranian female upper intermediate EFL learners selected based on their performance on TOEFL test from a group of 90 such students of Poyandegan Rahe Kish institute where the researcher teaches. These 60 learners were thence randomly assigned to two experimental groups each including 30 students.

A group of 30 learners with an almost similar language background took part in the piloting of the TOEFL prior to the actual administration. In order to select the target sample and to ensure the homogeneity of the participants, the vocabulary \& reading comprehension and structure sections of a TOEFL Test were administered to a population of 90 EFL learners from the same institute one week prior to the study. Based on the results obtained, the students whose scores were one standard deviation below and one standard deviation above the mean were selected and assigned randomly to two separate groups of control and experimental.

\subsection{Instruments}

As to the purpose of the study, a number of tests, materials, and rating rubrics were used in this study which are detailed below:

\subsubsection{TOEFL Test (pre test)}


To begin with, the researcher utilized a sample TOEFL to choose a homogenous sample of participants based on their level of proficiency prior to the study. The questions in the TOEFL are in multiple choice formats. Each question has four options, (A), (B), (C), (D); examiner must choose the correct one and fill in the corresponding oval on answer sheet. The TOEFL is given in one session of approximately 3 hours, including the time for examinees to be admitted. It consists of three sections: (1) Listening Comprehension, (2) Structure and Written Expression, (3) Vocabulary and Reading Comprehension.

\subsubsection{TOEFL Test (post test)}

Another sample TOEFL test section was conducted as the posttest to measure the improvement of the participants' grammar achievement in the two groups after four weeks of the treatment period.

\subsubsection{Course Book}

The textbook from which the tasks were extracted in this study is called Advanced English for Translation by Dennis Chamberlin Gillan White. This book is designed for upper-intermediate and more advanced students of all nationalities who need to use English in their work, whether in business, the tourist industry or the professions, or who are preparing for the Cambridge Certificate of Proficiency and similar examinations.

Finally, In order to help teachers to assess the standards required, there are several sample answers to the Translation Part with marks and examiner comments, Ranging from 1-5. The names of participants were removed from all of the written papers and were replaced with codes in a random order. The raters (each with MA degree in TEFL) thus had no information about the identity or the language background of any of the participants, other than the fact that students were non-native speakers in an upper-intermediate level. Importantly, too, none of the raters were informed that the study aimed to determine whether analyzing reading comprehension and translation practice markers had any significant effect on EFL learners' grammar achievement. Raters were asked to read the prompt that the students had been given for their assignment. Each participant's script was scored two times by two different raters.

\subsection{Procedure}

To begin the study, the researcher piloted a sample TOEFL Test among a group of 30 EFL participants. Following item analysis, the finalized version was administered for participant selection; the participants of this study included 60 Iranian female EFL learners selected based on their performance on the piloted TOEFL from a group of 90 students at Poyandegan Rahe Kish where the researcher taught. These 60 learners thence randomly were assigned to two experimental groups each including 30 students.

The researcher commenced the treatments by preparing a 12-session syllabus each session lasting one hour and 30 minutes. One experimental group received lessons on reading comprehension while the second experimental group was tutored through instruction of translation both of which were given the same lessons with a subtle difference in instruction of grammar, that finally the Translation Experimental Group outperformed the Reading 
Experimental Group.

It is necessary to mention that the first and the last session of instruction were dedicated to the pre and post tests and since the instruction of the syllabus in each session was similar and followed a specific pattern, only one single session of the instruction is explained.

In Reading Comprehension group first, the students were given an original copy of the passage. In each session, two approaches were used: the first phase, the detailed task or scanning: for each session, a series of questions, such as names of people, places, etc. were devised for students to scan. Next, the new additional questions were given to the students for skimming, the teacher/researcher tried to achieve the results through grammar and syntax through the questions.

After the students answered the questions devised by the teacher/researcher, the teacher would ask the students to study the grammar points together within the classroom, and then add two more examples of their own to the other examples. After the follow-up questions and responses, the teacher/researcher would run a discussion in class for fifteen minutes tops.

In Translation group, Before each session the teacher/researcher selected the first sentences of the grammar exercises for the students to translate, the teacher/researcher facilitated the process by pointing out the grammar implied in each sentence and helped the students (students work together in pairs) to translate those very sentences. Subsequently the teacher/researcher taught them to translate these sentences by paying attention to their intonation, stress and their rhythm in reading so she could find out whether they understood the message of the text. Whenever translating, they had to pay attention to the following principles: a) the rightness or wrongness of the source language influence; b) the style of the original text may be changed, depending on the purpose of the translation text; c) idioms have to work in L2, even though they are notoriously untranslatable.

In the next step, the students were told to compare their translations in pairs, and then the teacher/researcher gathered the final texts for final correction and brought their texts back for them the next session.

At the end of the treatment, both experimental groups sat for the posttest exam in order for the researcher to collect the related data based on which the difference of instruction would show the difference of the learners' mastery in terms of their grammar.

\subsection{Data Analysis}

In the present study, the data analysis provided descriptive and inferential statistics as well. Descriptive statistic like mean, standard deviation, standard error or the mean were obtained. Afterwards, to check the normality of distribution, skewness ratio was calculated. For inferential statistics, t-test was used in order to investigate any significant impact of reading comprehension and translation practice on EFL learners' grammar achievement. The SPSS software was used to obtain descriptive and inferential statistical results.

\section{Results}




\section{Macrothink

For the purpose of testing hypotheses, comprehensive descriptions of the findings are presented. A chronological order is applied in reporting the data analysis, thence, the participant selection process, the posttest, and the hypothesis testing are described in order with the discussion of the findings presented at the end of the chapter.

As discussed before, a TOEFL was used at the outset through which the participants were selected in terms of their general English proficiency and also one of the dependent variables of this study, i.e. grammar. Also, the TOEFL questionnaire was administered among the participants prior to the study.

\section{Descriptive Statistics of the TOEFL Piloting}

Following the piloting of the TOEFL, the descriptive statistics of this administration were calculated with the mean and standard deviation standing at 17.60 and 9.27 , respectively (Table 5.1).

Table 5.1. Descriptive Statistics of the TOEFL Piloting

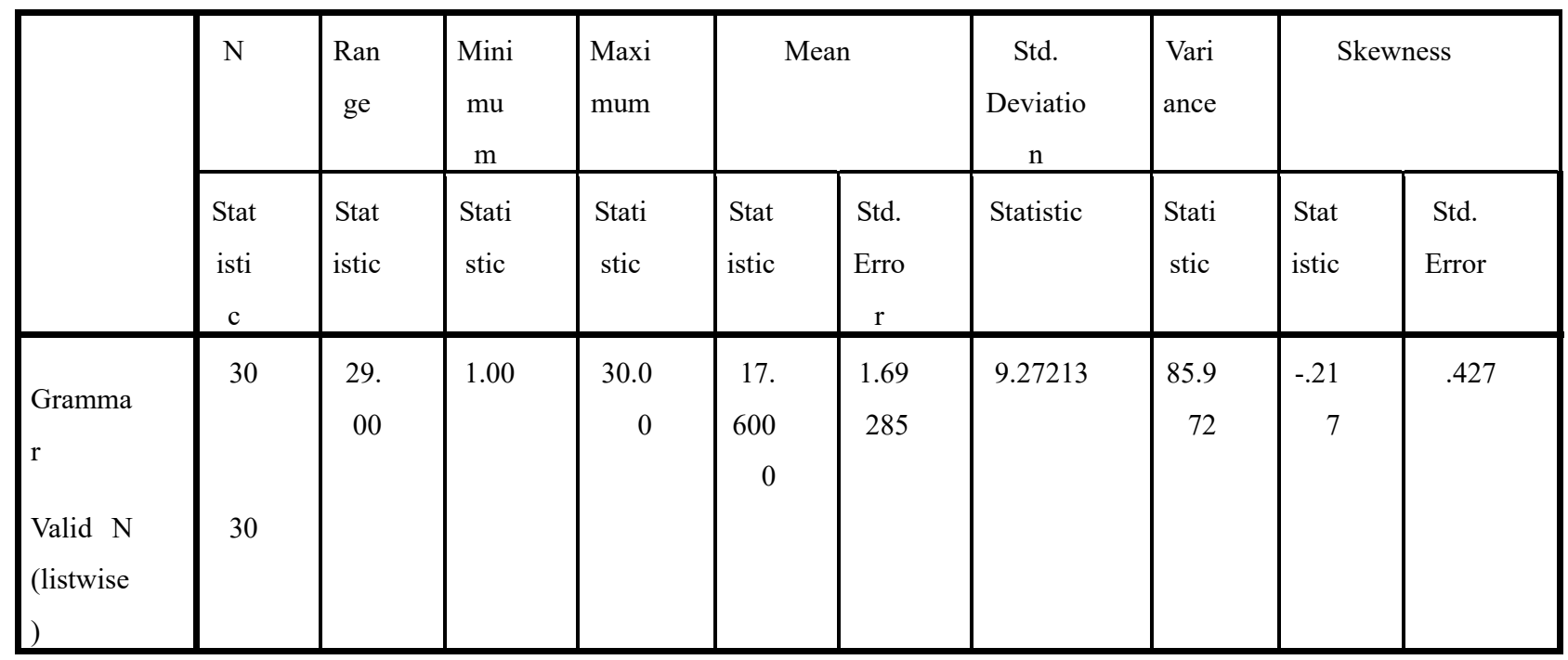

Figure 5.1 shows the histogram of the pilot participants' scores on the TOEFL. 


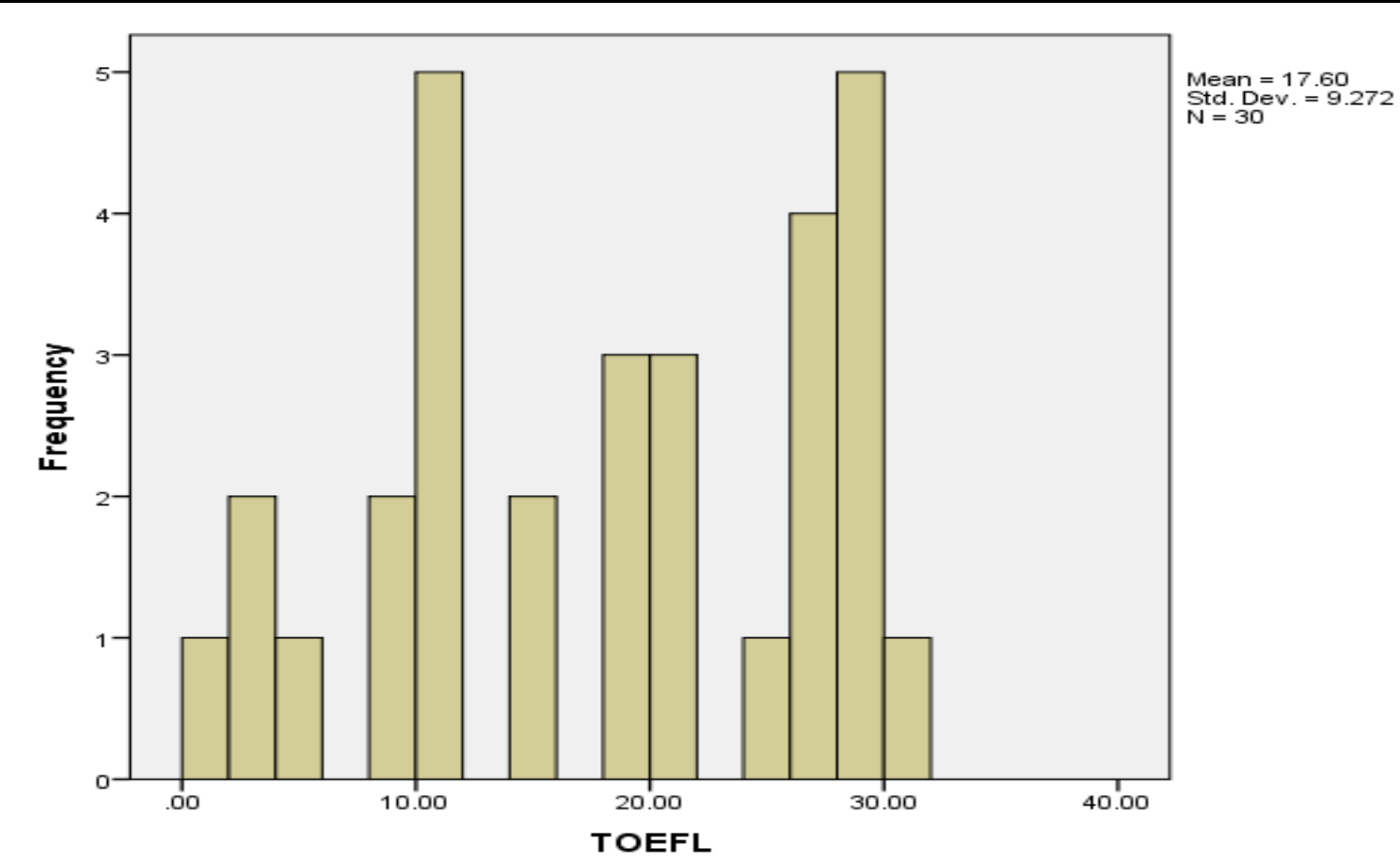

Figure 5.1 Histogram of the Scores Obtained on the TOEFL Piloting

Furthermore, the reliability of the test scores gained by the participants on the pilot TOEFL using Chronbach Alpha as shown in Table 5.2 - was 0.94.

Table 5.2. Reliability of the TOEFL in the Pilot Phase

\begin{tabular}{|c|c|c|}
\hline Cronbach's Alpha & $\begin{array}{c}\text { Cronbach's Alpha Based } \\
\text { on Standardized Items }\end{array}$ & No. of items \\
\hline .948 & .948 & 30 \\
\hline
\end{tabular}

Following the piloting, the TOEFL test was administered to 90 students with the aim of selecting 60 of them for the study. The descriptive statistics of this process are presented below in Table 5.3 with the mean and standard deviation being 11.78 and 3.45, respectively. 
Table 5.3. Descriptive Statistics of the TOEFL Piloting

\begin{tabular}{|l|c|c|c|c|c|c|c|}
\hline & $\mathrm{N}$ & $\begin{array}{c}\text { Mini } \\
\text { mum } \\
\text { mum }\end{array}$ & $\begin{array}{l}\text { Maxi } \\
\text { mean }\end{array}$ & $\begin{array}{c}\text { Std. } \\
\text { Deviation }\end{array}$ & \multicolumn{2}{|c|}{ Skewness } \\
\cline { 2 - 8 } & $\begin{array}{c}\text { Statis } \\
\text { tic }\end{array}$ & $\begin{array}{c}\text { Statist } \\
\text { ic }\end{array}$ & $\begin{array}{c}\text { Statist } \\
\text { ic }\end{array}$ & $\begin{array}{c}\text { Statis } \\
\text { tic }\end{array}$ & Statistic & $\begin{array}{c}\text { Statis } \\
\text { tic }\end{array}$ & $\begin{array}{c}\text { Std. } \\
\text { Error }\end{array}$ \\
\hline $\begin{array}{l}\text { TOEFL } \\
\begin{array}{l}\text { Valid } \\
\text { (listwise) }\end{array}\end{array}$ & 90 & 5 & 23 & 11.78 & 3.454 & .756 & .254 \\
\hline
\end{tabular}

Figure 5.2 below shows the histogram of the participants' scores on the TOEFL administration for homogenization.

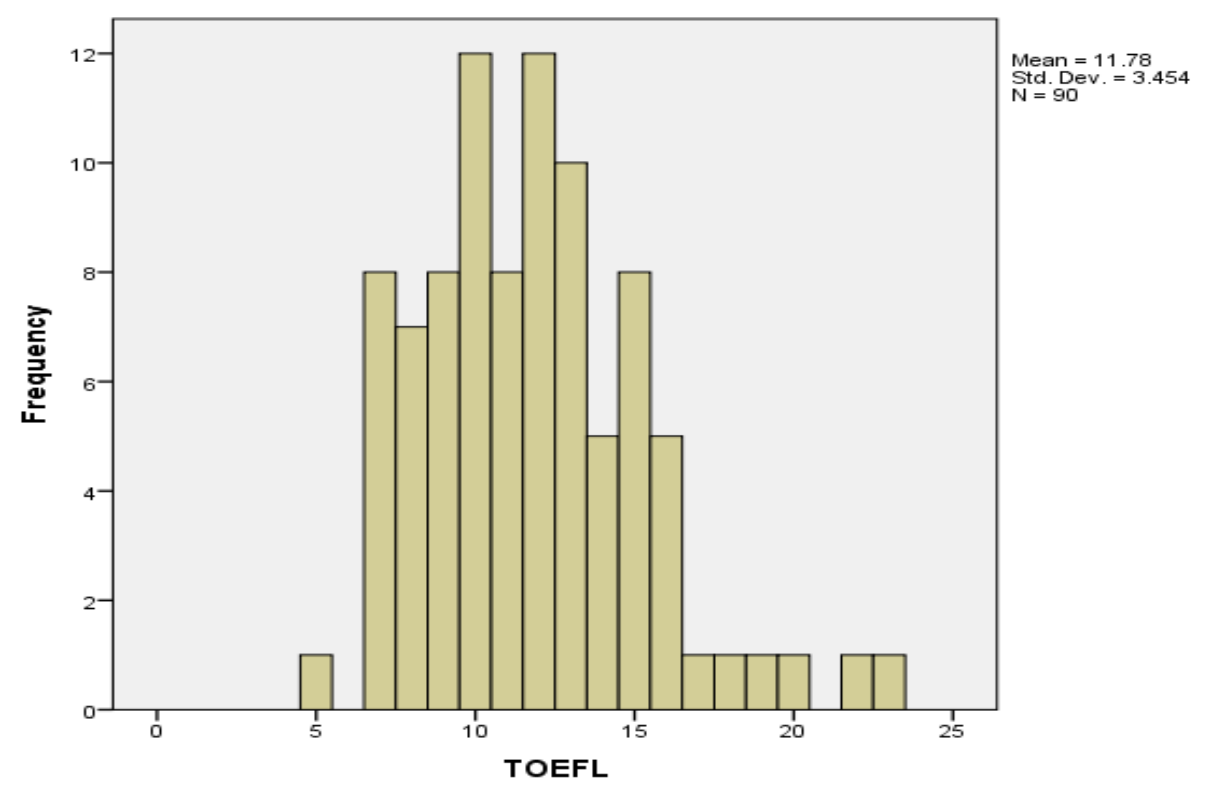

Figure 5.2. Histogram of the Scores Obtained on the TOEFL Administration

Out of the 90 participants, 60 whose scores fell between one standard deviation above and below the mean were chosen 
Table 5.4. Descriptive Statistics of the TOEFL grammar Scores of the Two Groups at the Outset

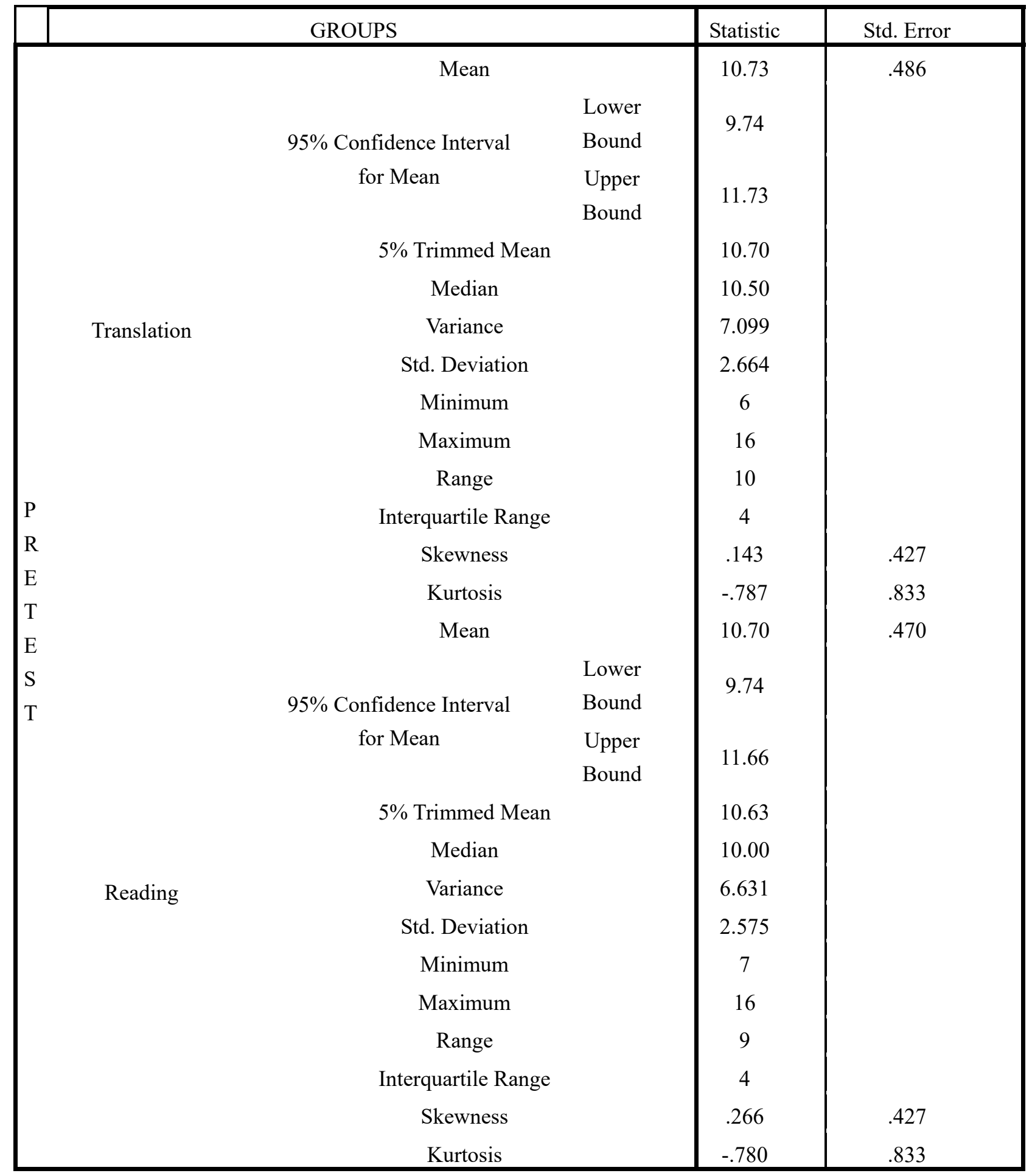




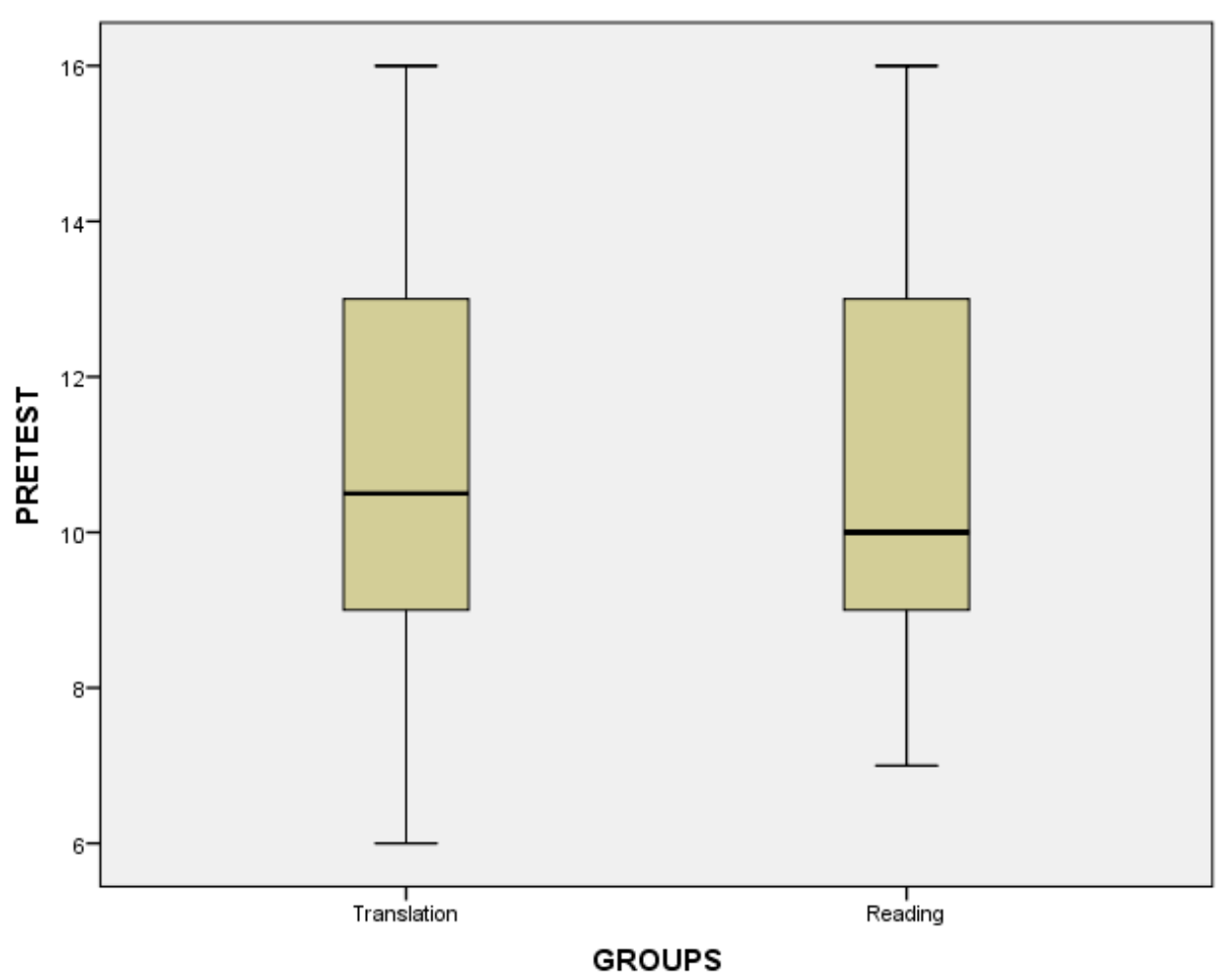

Figure 5.3. show the histogram of the above two groups' scores on the TOEFL pre test grammar sections.

Table 5.4 it shows the descriptive statistics of these two groups (translation and reading comprehension) based on their grammar achievement on post test scores. As both distributions manifested normality with their skewness ratios $(1.061,0.119)$ falling between the acceptable \pm 1.96 ranges, running an independent samples $t$-test was legitimized. 
Table 5.5. Descriptive Statistics of the TOEFL grammar Scores of the Two Groups on Post test

\section{Descriptives}

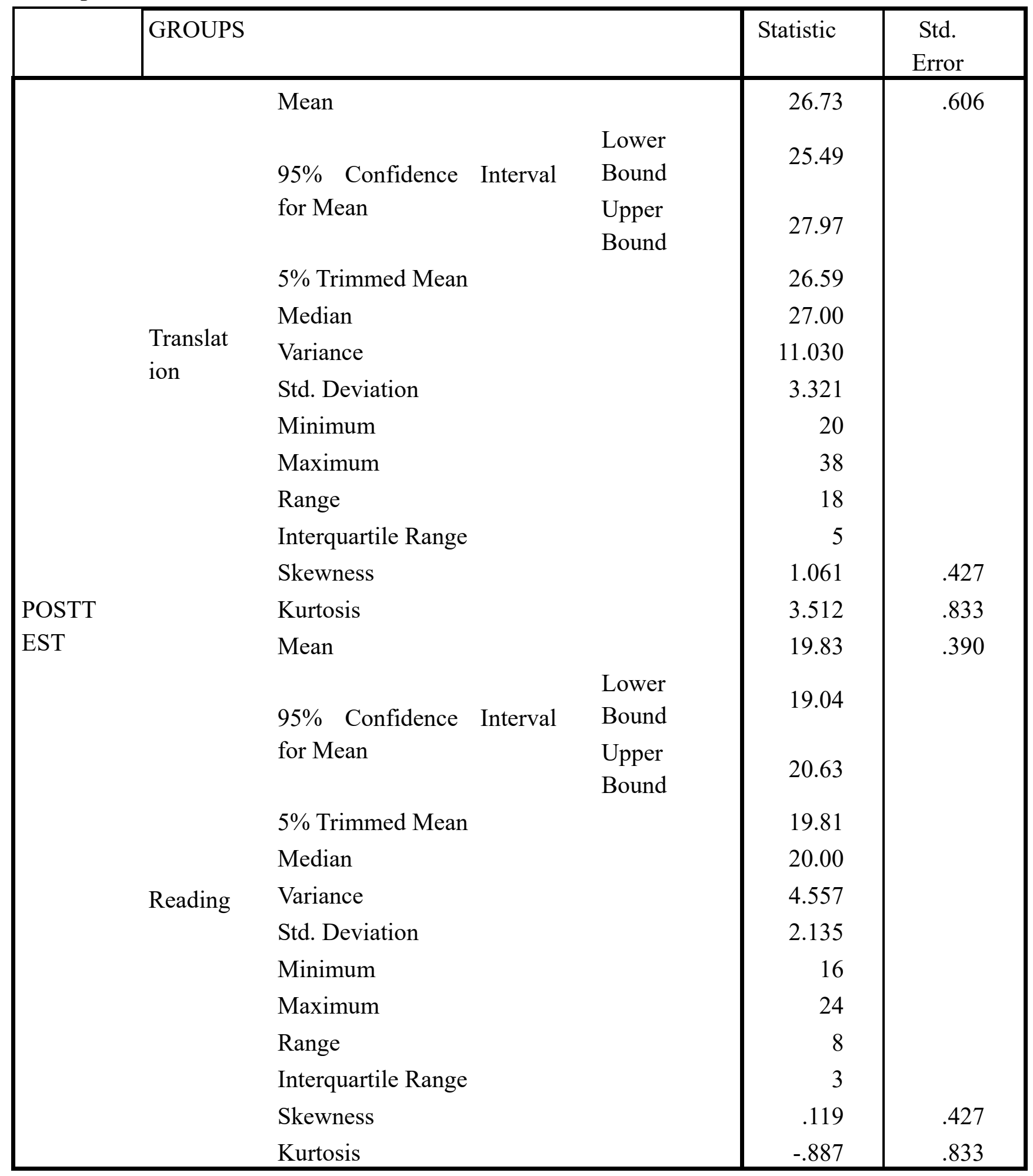




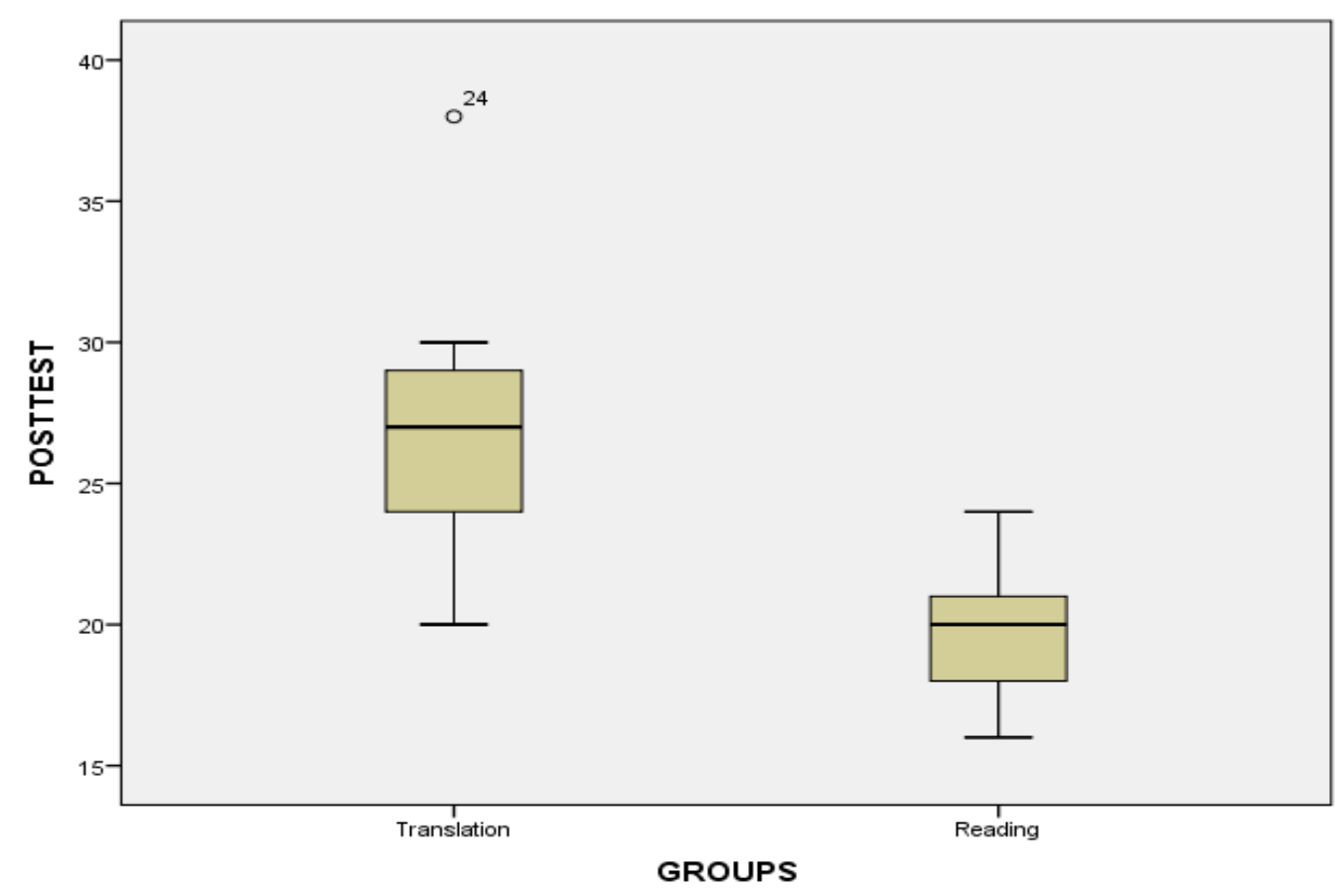

Figure 5.4 show the histogram of the above two groups' scores on the TOEFL post test grammar sections. That shows a better performance in translation group.

\section{The Results of Testing the Null Hypothesis}

As is evident in Table 5.6 below, with the $F$ value of 0.022 at the significance level of 0.884 being larger than 0.05 , the variances between the two groups were not significantly different. Therefore, the results of the $t$-test with the assumption of homogeneity of the variances were reported here. The results $(t=0.049, p=0.961>0.05)$ indicate that there was no significant difference between the mean scores of the two groups at the outset. Hence, any possible difference in the grammar of the two groups at the pretest could be attributed to the treatment. 


\section{Macrothink}

Journal of Studies in Education

ISSN 2162-6952

2015, Vol. 5, No. 4

Table 5.6. Independent Sample T-test for Control and Experimental Groups Grammar Pre-test

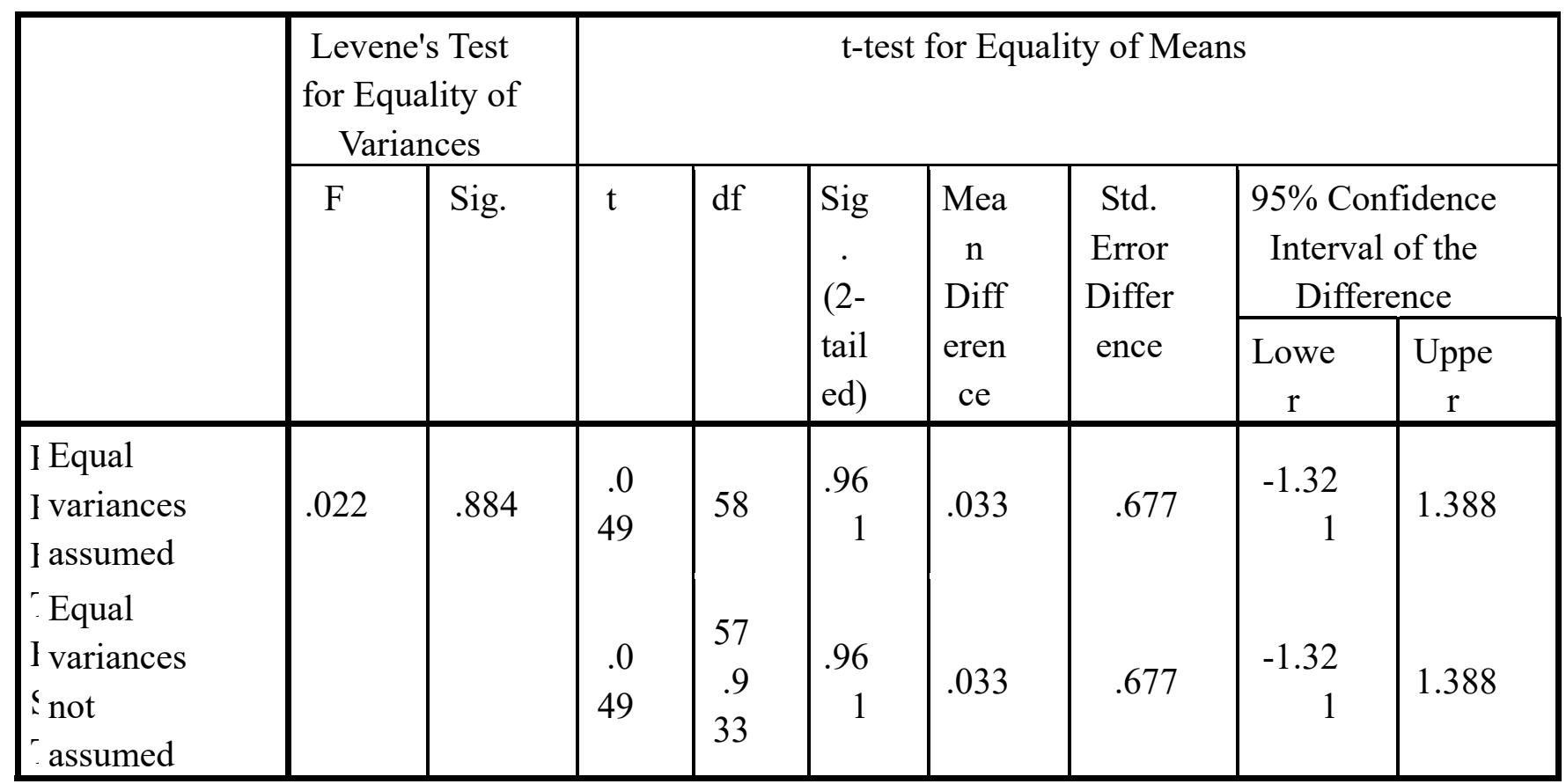

In order to check the null hypothesis of the study which stated that, There is no significant difference between the impact of reading comprehension and translation practice on EFL learners' grammar achievement the researcher needed to compare the mean scores of the experimental and control groups of the grammar post-test. For this purpose an independent sample t-test was legitimately run, as the distributions of scores for both groups proved to be normal. The subsequent table illustrates the corresponding statistics for the control and experimental groups' performance on post-test. 
Table 5.7. Independent Sample T-test for Control and Experimental Groups Grammar Post-test

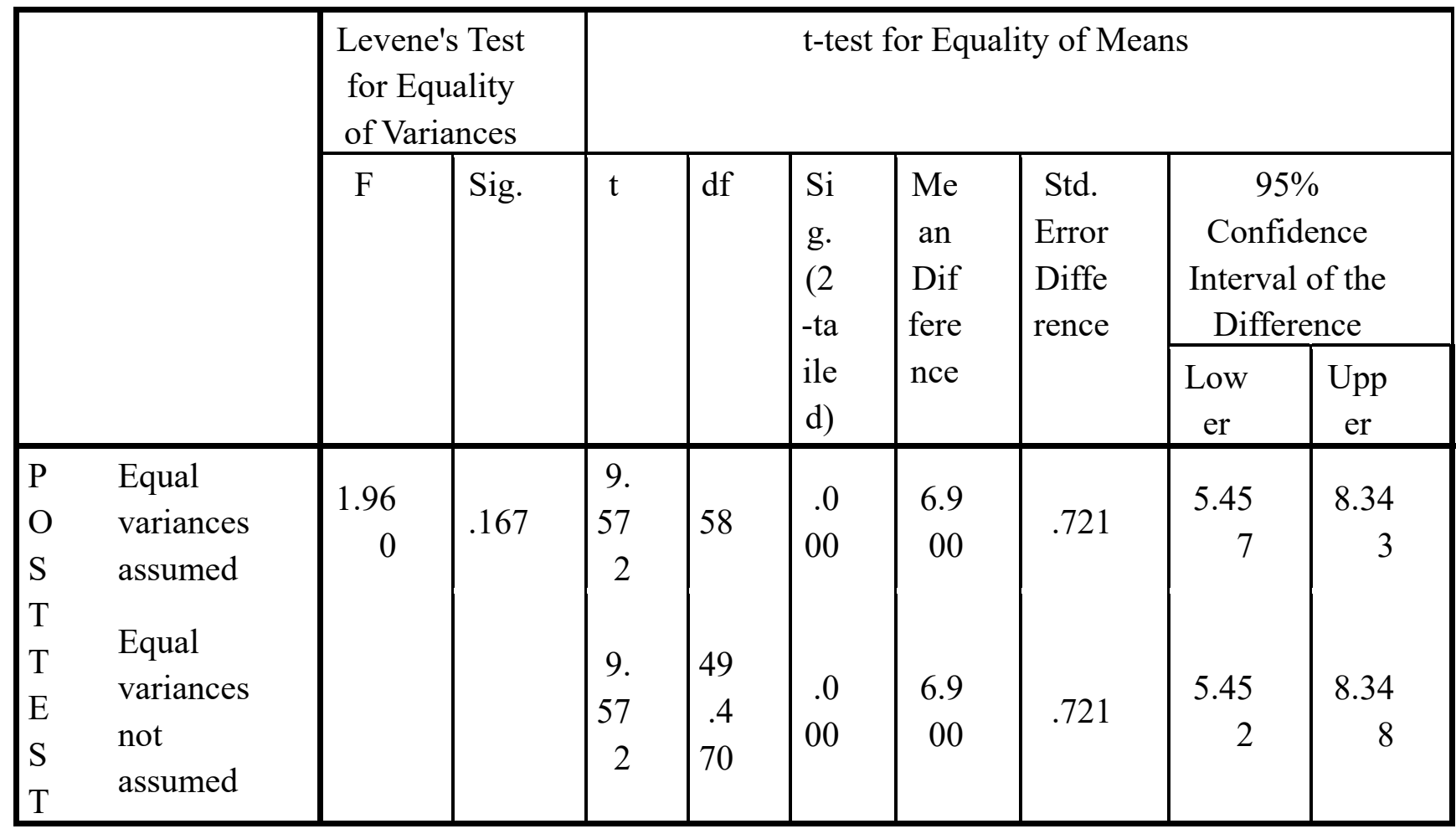

Considering the obtained results, the researcher could safely reject the null-hypothesis, which stated that There is no significant difference between the impact of reading comprehension and translation practice on EFL learners' grammar achievement, with $(t=9.572$, df $=58$, $p=0.000$ ), as the $\mathrm{p}$ value came out to be lower than 0.05 .

\section{Discussion}

The quest to find an answer to the research question 'Is there a significant difference between the impact of reading comprehension and translation practice on EFL learners' grammar achievement? ' led the researcher to conclude that analysing reading texts through translation does have a significant effect on EFL learners' grammar. In general, the results of this study lend further support to the idea that translation has a positive influence on grammar achievement.

The study was developed because the literature revealed that in the investigation of the improvement of the grammar, there were not much attempts to examine the effects of translation particularly on EFL learners' grammar achievement. Then, the results of the study indicated the outperformance of the translation experimental group over the reading experimental group in grammar achievement in case of the TOEFL test.

The importance of translation as an analytical tool therefore lies in its close association with the contexts in which it occurs. That is, the ways that writers present themselves, negotiate an argument, and engage with their readers.

The data analyses also revealed that the translation experimental group scores significantly 
differed from the scores of the participants in the reading experimental group. This is an evidence for the treatment effect. Hence, translation is suggested to be applied as a booster for the other skills. In other words, the study began with the intention of developing a means whereby language learners would be able to analyzed reading texts more efficiently. It is possible that this can ultimately result in the improvement of the other productive language skill, say, speaking.

\section{Conclusion}

Translation as a method of language teaching is still a subject under research and continues to be one of the most frequently discussed topics among linguists, methodologists and teachers. However, the present study shows that translation activities are a useful pedagogical tool. When introduced purposefully and imaginatively into language learning programme, translation becomes a suitable language practice method for many students. When integrated into daily classroom activities translation can help students develop and improve reading, speaking, writing skills, grammar and vocabulary. Translation in foreign language classes enhances better understanding of structures of the two languages and also strengthens students' translation skills. It is an effective, valid tool in the foreign language learning and can be used in the university classroom to improve knowledge in English. Still, translation should not be overused and should be integrated into language teaching at the right time and with the right students.

\section{References}

Aebersold, J. A. \& Field, M. L. (1997). From reader to reading teacher: Issues and strategies for second language classrooms. Cambridge, England: Cambridge University Press, 43-45.

Akannan. (2009). What are some factors affecting reading? Retrieved January 26, 2010, from http://www.enotes.com/science/group/discuss/what-some-factors-affecting- reading-51.htm.

Block, E. (1986). The comprehension strategies of second language readers. TESOL Quarterly, 20(3), 63-490.http: dx.doi.org/10.2307/3586295

Brown, H. D. (2002). Principles of Language Learning and Teaching. 4th ed. New York: Longman.

Brumfit \& Johnson, (1979). The Communicative Approach to Language Teaching. Oxford: Oxford University Press.

Casagrande,G.(2008).Ramblings on the Origins of Grammar: Rules. Retrieved Decembe18.2009.fromhttp://www.redroom.com/blog/junecasagrande/ramblings-origin-gram mar- rules.

Catford, J. (1965). A Linguistic Theory of Translation. London: Oxford Univercity Press. PMid:19994369 PMCid:PMC1898316

Chamot, A. U., Barnhardt, S., El-Dinary, P. B., \& Robbins, J. (1999). The learningstrategies handbook. New York: Longman. PMCid:PMC93569 


\section{Macrothink}

Journal of Studies in Education

ISSN 2162-6952

2015, Vol. 5, No. 4

Collins, D.N., \& Aiex, K.N. (1995). Gifted Readers and Reading Instruction. Retrieved January 18, 2010, from http://www.ericdigests.org/1996-1/readers.htm

Cook, G. (2001). Language teaching, using of translation in. In M. Baker (ed.), Routledge Encyclopedia of Translation Studies. London: Routledge, 117_120.

Cook, V. (1991). Second Language Learning and Language Teaching. London: Edward Arnold, a Division of Hodder \& Stoughton.

Day, R \& Bamford, J. (1998). Extensive Reading in The Second Language Classroom. Cambridge, England: Cambridge University Press.

Dorit, Sasson. (2010). Why Reading Strategies? Associated Content, Inc. Retrieved April 15, 2010 from http: //www.associatedcontent.com/article/464566/

Duff, A. (1994). Translation: Resource Books for Teachers. Oxford: OxfordUniversity Press.

Dutcher, P. (1990). Authentic Reading Assessment. Retrieved January 18, 2010, from http://www.ericdigests.org/pre-9218/reading.htm

Eastman, C. (2009). History of Grammatical study. In Microsoft Encarta (2009).

Garrett, N. (1986). The problem with grammar: What kind can the language learner use? Modern Language Journal 70, 133-4. http://dx.doi.org/10.1111/j.1540-4781.1986.tb05257.x

Halliday, M.A.K. (1990). An introduction to functional grammar. Melbourne: Hodder \& Stoughton.

Hartwell, P. (1985). Grammar, grammars, and the teaching of grammar. College English 47, 105-27.http:dx.doi.org/10.2307/376562

Harmer, J. (2001). The Practice of English Language Teaching. Oxford: Oxford University Press.

Holmes, J.S. (2000). The name and nature of translation studies. Amsterdam: Translation Studies Section, Department of General Literary Studies, University of Amsterdam.

Hubbard, P., H. Jones, B. Thornton, and R. Wheeler. (1983). A Training Course for TEFL. Oxford: Oxford UP.

Jakobson, Roman, (2000). On Linguistic Aspects of Translation (2 ${ }^{\text {nd }}$ Edition). New York: Routledge. PMCid:PMC86176

Kern, R. G. (1994). 'The role of mental translation in second language reading' Studies in Second Language Acquisition, 16, 441-461.htp://dx.doi.org/10.1017/s0272263100013450

Larsen-Freeman, (2000). Techniques and Principles in Language Teaching. (2nd ed.) Oxford: Oxford University Press.

Larsen-Freeman, D. (2003). Teaching Language - From Grammar to Grammaring Boston: Heinle. 


\section{Macrothink}

Journal of Studies in Education

ISSN 2162-6952

2015, Vol. 5, No. 4

Larsen-Freeman,D. (1997). Grammar \&Its Teaching:Challenging the Myths.Retrieved December 18,2009,from http://www.ericdigests.org/1997-4/grammar.htm

Le, T., \& Le,Q. (n.d.). (2009). Asian Students' Perceptions of Grammar Teaching in the ES classroom.Retrieved December 18, from http://www.educ.utas.edu.au/users/tle/JOURNAL/ ISSN 1327-774X

Leech, G. (1994). Students' Grammar-Teachers' Grammar-Learners' Grammar. Grammar and the Language Teacher. Prentice Hall International, Ltd.

Macaro, Ernesto. (2003). Teaching and Learning a Second Language: A Guide to Recent Research and its Applications. Continuum International Publishing Group. 208 pages.

Mcnamara, Danielle.S.(2007). Reading Comprehension Strategies: Theories Interactions, and Technologies. Laurence Erablaum Associates, 6.

Méndez R. F. \& Pérez Vallejo J. D. (n.d.). Writing and Translation. Retrieved November 20, 2009, from http://www.translationdirectory.com/article427.htm

Munday, Jermy, (2001). Introducing Translation Studies: Theories and Applications. New York: Routledge.

Nordquist,R.(n.d.). (2009). Grammar \& Composition. Retrieved December 18, from http:/www.grammar.about.com/od/tz/g/trangrammterm.htm

Pang, Elizabeth S. et all (2003). Teaching Reading. International Academy of Education, 6. Retrieved April 9, 2010 from http//www.ibe.unesco.org/publications

Pinker, Steven. (1994). The Language Instinct: How the Mind Creates Language. New York: Perennial-HarperCollins Publishers. http://dx.doi/org/10.1037/e412952005-009

Quirk, R, S. Greenbaum, G. Leech, and J. Svartvik. (1985). A Comprehensive Grammar of English. London and New York: Longman.

Selinker, Larry and Susan M.Gass. Second Language Acquisition. Mahwah: Lawrence Erlbaum Associates, 2001. 488 pages.

Seng, G. H., \& Hashim F. (2006). Use of L1 in L2 reading comprehension among tertiary ESL learners. Reading in a Foreign Language, 18(1).

Sibbard, Richard. (1994). The Use of Translation in Foreign Language Teaching.

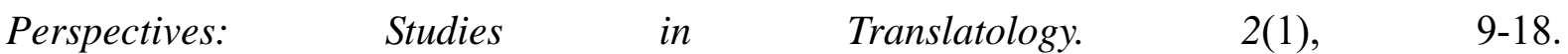
http://dx.doi.org/10.1080/0907676x.1994.9961218

Swan, M. (1994) "Design criteria for pedagogic grammar rules" in Bygate M., Tonkyn, A. \& Williams, E. (eds.) “Grammar and the Language Teacher” Longman, 45-55

Tomlin, R.S. (1997). Functional grammars, pedagogical grammars, and communicative language teaching [in:] T. Odlin (ed.) Perspectives on Pedagogical Grammar. Cambridge: Cambridge University Press. 
Vacca. Anee L. et al. (1996). Reading and Learning to Read. (6thed.).Pearson.

Vinay,J. P., \& J. Darbelnet, (1977). Comparative Stylistics of French and English: A Methodology for Translation. Amsterdam: John Benjamins Publishing Co.

Weaver, Constance. (1979). Grammar for Teachers: Perspectives and Definitions. Urbana, Illinois: NCTE.

Westney, P. (1994) Rules and Pedagogical Grammar in Odlin, T. (ed.), 72-96. http://dx.doi.org/10.1017/cbo9781139524605.006

Widodo,H. (2006). Approaches \& Procedures for teaching grammar. Retrieved December18,2009, from http://education.waikato.ac.nz/research/files/etpc/2006v5n1nar1.pdf Widdowson, H.G. (1978). Teaching Language as Communication. Oxford: OUP. 168 pages.

Williams, James D. (1999). The Teacher's Grammar Book. Mahwah, N.J.: Lawrence Erlbaum Associates, Publishers. 